\title{
Survey on Occurrence of Parasitic Diseases in Carp Culture Ponds of West Godavari, Andhra Pradesh
}

\author{
T. Suguna* \\ Fisheries Research Station, S.V. Veterinary University, West Godavari, Andhra Pradesh - 534 \\ 199, Mobile No: 098480 19367, India \\ *Corresponding author
}

\begin{abstract}
A B S T R A C T
\section{Keywords}

Carps, Causes of occurrence,

Controlling measures, Diseases, Etiological agents

\section{Article Info}

Accepted:

17 September 2020

Available Online:

10 October 2020

Aquaculture is one of the fastest growing food producing sectors in the world. In India over the last three decades, aquaculture has developed significantly, earning considerable amount of foreign exchange, besides providing employment. Freshwater aquaculture has been the main stay of Indian aquaculture, in terms of total quantity as well as its share in the domestic fish basket. India is called as carp country as carp production contributes in bulk (over 82\%). In Andhra Pradesh fish and shrimp culture is income generating profession. The district West Godavari of Andhra Pradesh, is specifically the fish bowl of India, generating an amount of Rs. 15.00 crores annually. Semi intensive culture practice is common, in an area of more than 2.0 lakh acres. In course of expansion and intensification of this semi extensive culture practice of the Indian major carps, over the last three decades, many economically important problems have been identified which are threatening the sustainability of the culture system. Occurrence of diseases is one of such factor affecting the socio-economic status of aqua farmers. To overcome this, an intensive surveillance was carried to document the prevalence of various diseases, season of occurrence, disease diagnosis, etiological agents, mortality rates and controlling measures, so that the severe risk for sustainability and huge economic loss can be arrested. The frequency in occurrence of dactylogyrosis, paradactylogyrosis, myxosporiasis and argulosis are recorded. The incidence of diseases and mortality rate are high in winter season.
\end{abstract}

\section{Introduction}

Aquaculture in India is a progressively growing food production system which fulfils adequate requirement of protein sources to the society globally. India is the second largest fish producing country (DADF; 2016). The sector has shown significant growth from traditional culture practices to commercial methods of culture, enhancing fish production from a mere 7.5 lakh tonne in 1950-51 to 107.95 lakhs tonne during 2015-16, earning crores of rupees through export of fish to different countries (Mishra et al., 2017). In Andhra Pradesh, this aqua sector has benchmarked from a domestic activity to an enterprise, where in the indigenous major carps: Catla (Catla catla), rohu (Labeo 
rohita), mrigal (Cirrhinus mrigal), exotic carps like common carp (Cyprinus carpio) grass carp (Ctenopharyngodon idella), silver carp (Hypophthalmicthys molitrix) along with air breathing fishes, Clarias batrachus, Heteropneuestes fossils, Pangasius sps. are being widely cultured accounting for bulk of freshwater aquaculture production. In the last few years, the exotic catfish Pangasianodon hypophthalmus and pacu Piaractus branchypomus culure is also increasing. Tilapia and Pangasius are, also offer opportunities for cage culture. The focus on the production of genetically improved tilapia for market as cheep source of proteins is also enhancing (Jelte de Jong, 2017). In Andhra Pradesh, fish and shrimp culture is predominant income generating profession. Further, this state leads first in position in aquaculture production of the nation. In the state, it is estimated that more than $80 \%$ of the fish production arise from the fish bowl area i.e. Krishna, East Godavari and West Godavari districts. Of these districts, West Godavari plays a lead role especially in freshwater fish production. Production of IMC i.e. Catla, Rohu and Mrigala contribute $80-85 \%$ of total fish production. With a culture area of 2.0 lakh acres the aqua production of the district is 10,51,754 tones (17-18), 10.00 lakh metric tons (18-19) and 11.0 lakh metric tons (19-20) respectively.

In spite of the unprecedented development of semi intensive culture of Indian major carps, many economically important problems has been identified, that are threatening the sustainability of the culture system. The expansion and intensification of aqua farming practices lead to health problems in culturing fishes, thereby reducing the production rate. The degraded environmental parameters, also influenced the occurrence of infectious diseases. Disease is one of the major constraint to aquaculture and limiting factor for economic and socio-economic development in India and also as in many other countries of the world (Begum et al., 2013, Mohan et al., 2002; Sahoo, 2013). Some disease have caused serious damage, not only the livelihood of fish farmers, but also to the future development of the industry. Many diseases affecting present day aquaculture is resultant of intensification of culture practices (Walker and Winton, 2010) without the basic perception of intricate balance between host, pathogen and environment (Bondad - Reantaso et al., 2005; Subasingha et al., 2001). In Andhra Pradesh the increase in aqua production particularly in expansion into intensive and semi intensive methods of production has been coupled by increase in fish and shell fish resulting from high stocking densities and stress condition that favours the occurrence and spread of infectious diseases (Das, B.K., Mishra, S.S., 2014). 1) As the scope for horizontal expansion is limited, the current trend in aquaculture development is focused towards intensification of the culture practices. The vertical expansion of fish culture with diversified species and high stocking density has resulted in more frequent occurrence of bacterial, parasitic and viral pathogens, often leading to higher morbidity or mass mortalities and lowered production. 2) The frequent occurrence of diseases and epizootics are considered to be major bottlenecks for increasing production. The diseases are mostly bacterial and parasitic origin. The diseases account for 10-5\% towards the production cost (Sahoo et al., 2017). The occurrence of disease is a result of the complex interaction between the host, pathogen and the environment (Snieszko, 1974). In aquatic systems, disease management is a difficult proposition due to the unique ecosystem, where the pathogen is always looking for an opportunity when the health status of the host is comprised (Vijayan and Sanil, 2012). In many cases, diseases out breaks are closely related to environmental 
deterioration, leading to stress to the cultured animals. Different stress factors such as non optimal water quality, higher microbial load, poor nutritional status, high stocking density will trigger the chances of infection by opportunistic pathogens in aquatic environment (Mishra et al., 2015). Most bacterial, parasitic and fungal pathogens are not strictly parasitic micro organisms. These pathogens have a high adaptability to environmental changes. If the conditions for parasitism are unsuitable, saprophytic relationship will develop. Environmental stress factors and organic loadings are identified as causes for further infections (Shaovi Li, 1989). Lack of knowledge of fish health management and skill to prevent and control disease outbreak is leading to huge economic loss (Bagum et al., 2013). This study throws light on various diseases, frequency and seasonal variation in occurrence, etiological agents, mortality rate and also controlling measures.

\section{Materials and Methods}

The samples of fish (1073) and water (2118) were collected fortnightly, from various ponds of different villages of 242 aqua farmers from 2019 April to 2020 March in West Godavari. The water sample were analysed for various physical and chemical factors by following standard procedures. The fish are disease diagnosed, morphologically and microscopically in our Aquatic Animal Health Referral Laboratory, Fisheries Research Station, Sri Venkateswara Veterinary University, Undi, Bhimavaram, West Godavari district. Anamnesis and parasitological diagnosis were performed and recorded.

The gills and other internal organs were excised and maintained into petri dish with $0.65 \%$ saline solution. The slime mount of gill were studied microscopically for diagnosis of internal parasites. A scraping of body surface mucus in skull - tail direction was performed to search for parasites microscopically. The severity of disease is recorded by observation of internal organs.

\section{Results and Discussion}

Carp culture area of 4964 acres was surveyed in West Godavari district, covering 242 aqua farmers from twenty villages (Table 1). The size of the culture ponds ranged from 5-25 acres. The incidence of 1132 cases of parasitic diseases and their receptive etiological agents were recorded (Table 2 and 3) during the survey study.

Table.1 Location of the surveyed carp culture ponds in West Godavari district, Andhra Pradesh

\begin{tabular}{|l|l|}
\hline Pedapulleru & Malvanithippa \\
\hline Eelampudi & M.M. Puram \\
\hline Fathepuram & Alapadu \\
\hline Dirsumarru & Tadinada \\
\hline Undi & Tummaguppa \\
\hline Ai. Bhimavaram & Sriparru \\
\hline Bondada lanka & Kalavapudi \\
\hline Pedakapavaram & Poola \\
\hline Akividu & Agadalalanka \\
\hline Siddapuram & Nidamarru \\
\hline
\end{tabular}


Table.2 Common diseases recorded from carp farming ponds

\begin{tabular}{|c|l|l|l|l|}
\hline S1. No. & \multicolumn{2}{|c|}{ Disease condition } & \multicolumn{1}{|c|}{ Symptoms } & Etiological agent \\
\hline A. & Parasitic diseases: & $\begin{array}{l}\text { Most fish are susceptible whitish } \\
\text { cysts, mostly observed on skin, fins } \\
\text { and gills. }\end{array}$ & Ichthyophthirius sps. \\
\hline $\mathbf{2 .}$ & Ich / white spot & Trichodiniasis & $\begin{array}{l}\text { Most fish susceptible, whitish cysts } \\
\text { on skin, fins, gills disc shaped, } \\
\text { spherical cysts can be observed } \\
\text { under microscope. }\end{array}$ & Trichodina sps. \\
\hline $\mathbf{3 .}$ & $\begin{array}{l}\text { Dactylogyrosis } \\
\text { fluke) }\end{array}$ & (gill & $\begin{array}{l}\text { Mostly affects gills, destroying the } \\
\text { gill filaments, gills with clumps of } \\
\text { white masses. Parasites can be } \\
\text { observed under microscope. }\end{array}$ & Dactylogyrus sps. \\
\hline $\mathbf{4 .}$ & $\begin{array}{l}\text { Gyrodactyloris } \\
\text { fluke) }\end{array}$ & (skin & $\begin{array}{l}\text { These grow on and destroy the } \\
\text { skin, gills with clumps of white } \\
\text { masses, frequently associated with } \\
\text { secondary infection. }\end{array}$ & Gyrodactylus sps. \\
\hline $\mathbf{5 .}$ & Argulosis (carp lice) & $\begin{array}{l}\text { Wide spread on most farmed fish, } \\
\text { parasite seen moving on skin } \\
\text { surface, causing lesions with } \\
\text { secondary bacterial infections, } \\
\text { haemorrhagic spots and ulcers. }\end{array}$ & \\
\hline 6. & Myxosporidiasis & $\begin{array}{l}\text { Parasite produce cysts on gill } \\
\text { filaments usually, fish becomes } \\
\text { weak, falling of scales. }\end{array}$ & Myxosporiadium sps. \\
\hline
\end{tabular}

Table.3 The percentage of disease incidence of main bacterial diseases during April 19 to March 20

\begin{tabular}{|c|c|c|}
\hline Sl. No. & Disease & Cases \\
\hline \multirow[t]{10}{*}{ I. } & Parasitic disease & 1132 \\
\hline & a. Helminth & \\
\hline & - Dactylogyrosis & $491-43.3 \%$ \\
\hline & - Paradactylogyrosis & $484-42.7 \%$ \\
\hline & b. Protozoan & \\
\hline & - Myxosporiasis & $111-9.8 \%$ \\
\hline & - Trichodiniasis & $22-2.1 \%$ \\
\hline & c. Crustacean & \\
\hline & - Argulus & $24-2.1 \%$ \\
\hline & - Lernaea & 10 \\
\hline
\end{tabular}


Table.4 The percentage of mortality of fish in culture ponds (month wise)

\begin{tabular}{|l|l|}
\hline April 2019 & $\mathbf{6 . 2 6 \%}$ \\
\hline May 2019 & $4.78 \%$ \\
\hline June 2019 & $5.86 \%$ \\
\hline July 2019 & $5.62 \%$ \\
\hline August 2019 & $5.24 \%$ \\
\hline September 2019 & $7.56 \%$ \\
\hline October 2019 & $9.80 \%$ \\
\hline November 2019 & $10.30 \%$ \\
\hline December 2019 & $17.17 \%$ \\
\hline January 2020 & $13.23 \%$ \\
\hline February 2020 & 7.60 \\
\hline March 2020 & $12.39 \%$ \\
\hline
\end{tabular}

Table.5 Water temperature data (range) in ponds during April 19 to March 20

\begin{tabular}{|l|l|}
\hline $\mathbf{p H}$ & $\mathbf{7 . 5}-\mathbf{8 . 5}$ \\
\hline Salinity & $0-3.8 \%$ \\
\hline Dissolved oxygen $(\mathbf{m g} / \mathbf{l})$ & $2.8-4.8$ \\
\hline Total alkalinity $(\mathbf{m g} / \mathbf{l})$ & $120-450$ \\
\hline Total hardness $(\mathbf{m g} / \mathbf{l})$ & $100-500$ \\
\hline Total ammonia & $0.01-2.3$ \\
\hline
\end{tabular}

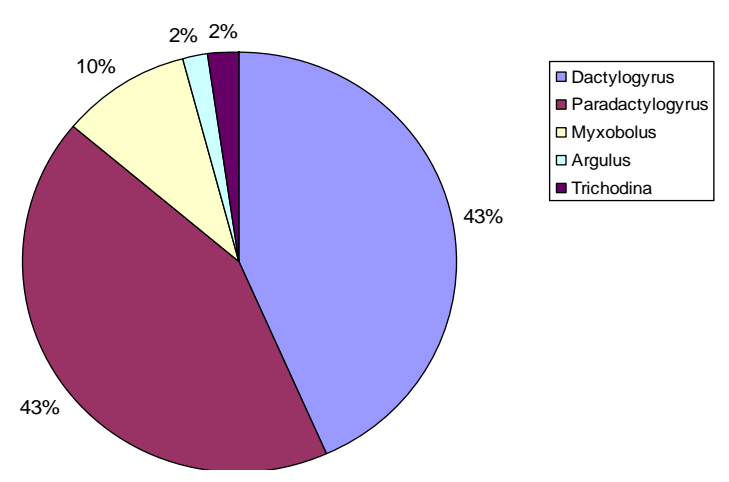

Fig.1 Incidence of parasitic diseases

Helminth etiological agents

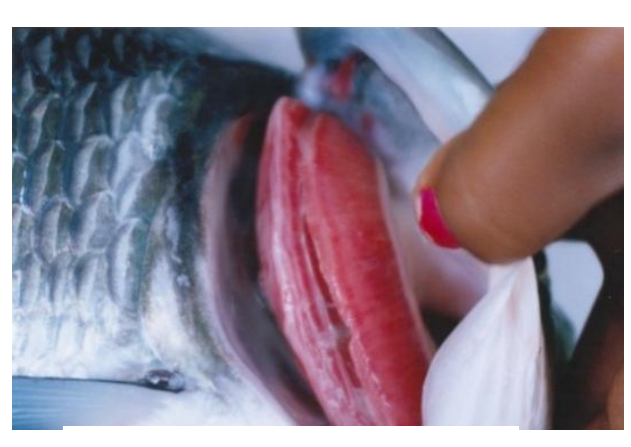

Fig.2a Paradactylogyrus

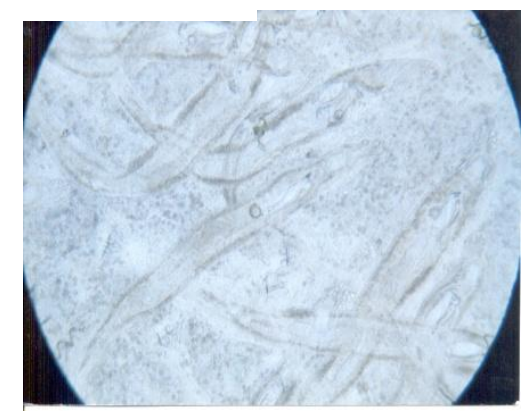

Fig.2b Dactylogyrus 


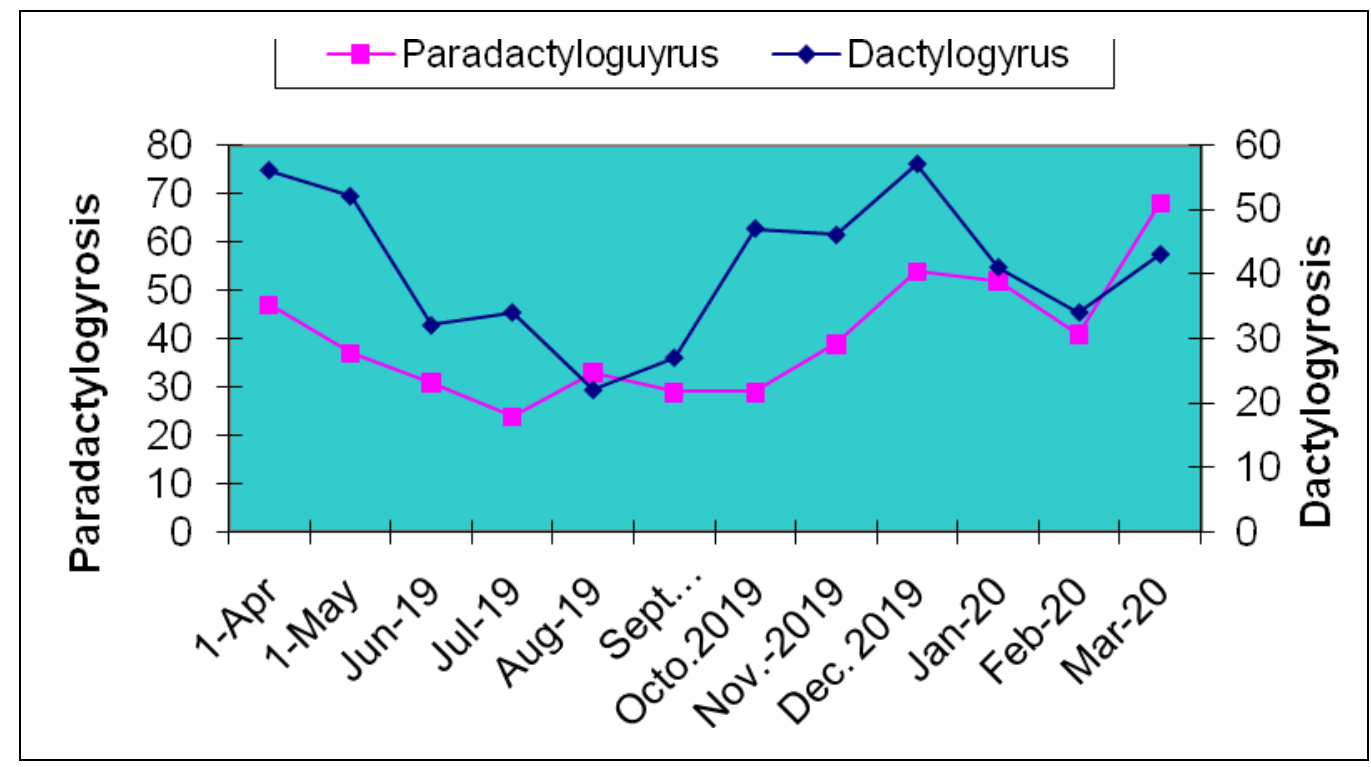

Fig.3 Incidence of helminth parasitic disease

Protozoan etiological agents

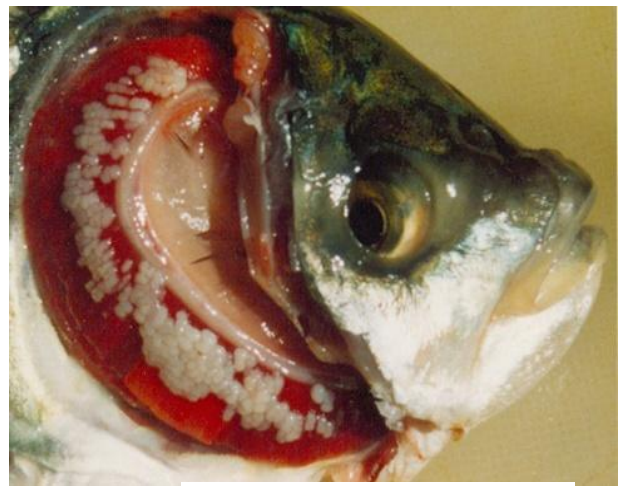

Fig.4a Myxobolus

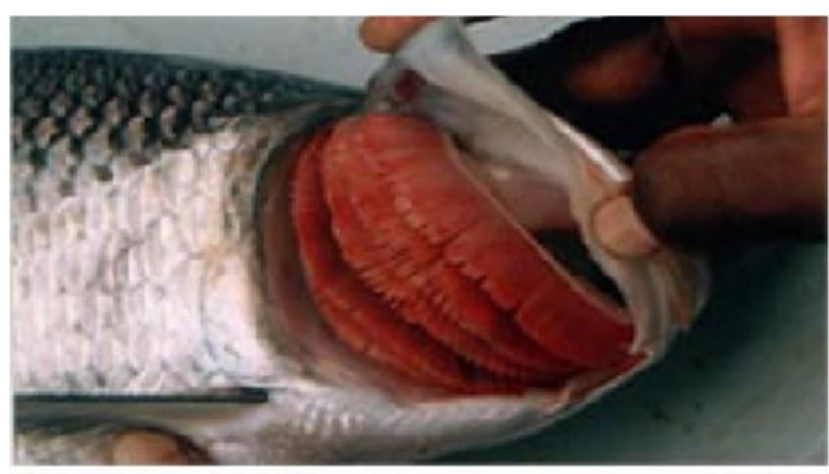

Fig.4b Trichodina

$\multimap-$ Myxobolus $\multimap$ Trlchodina

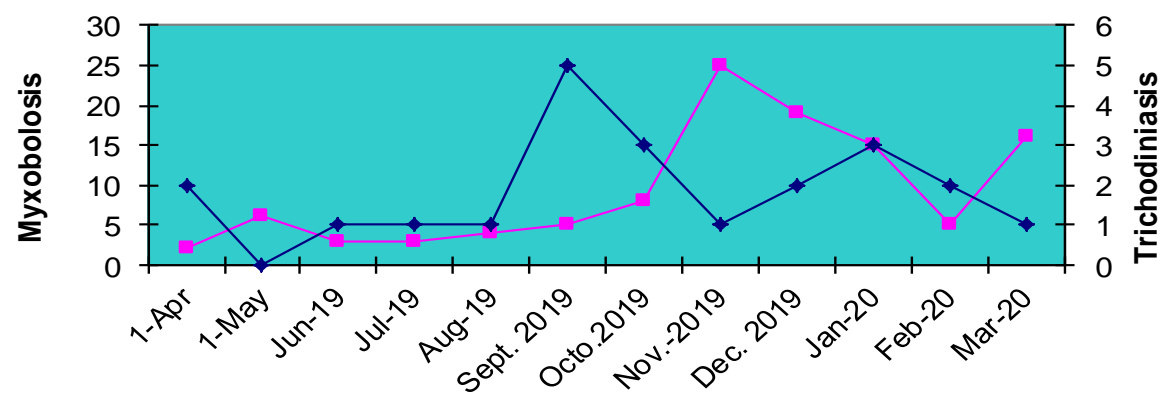

Fig.5 Incidence of protozoan parasitic disease 
Crustacean tiological agents

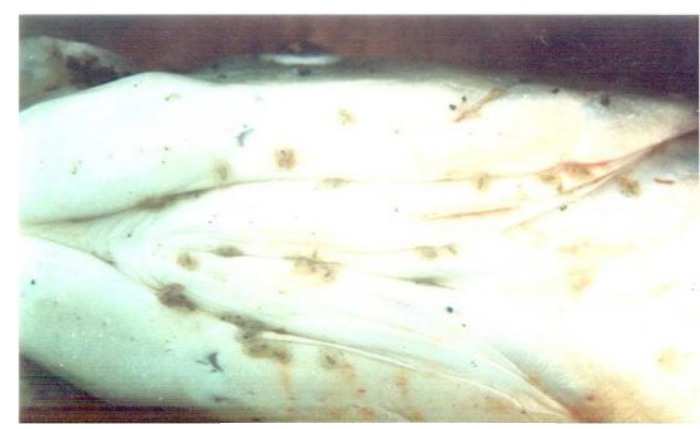

Fig.6a Argulus

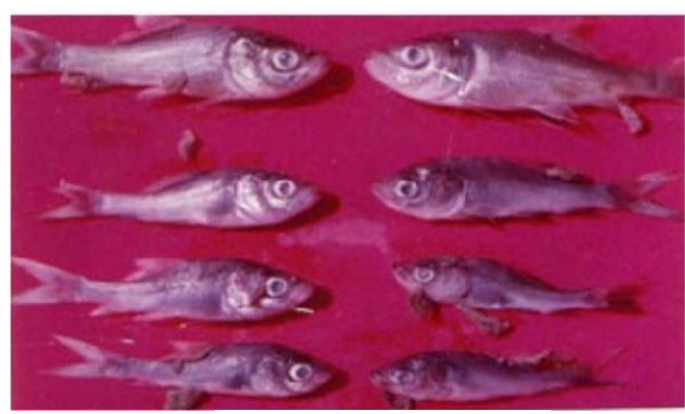

Fig.6b Lernaea

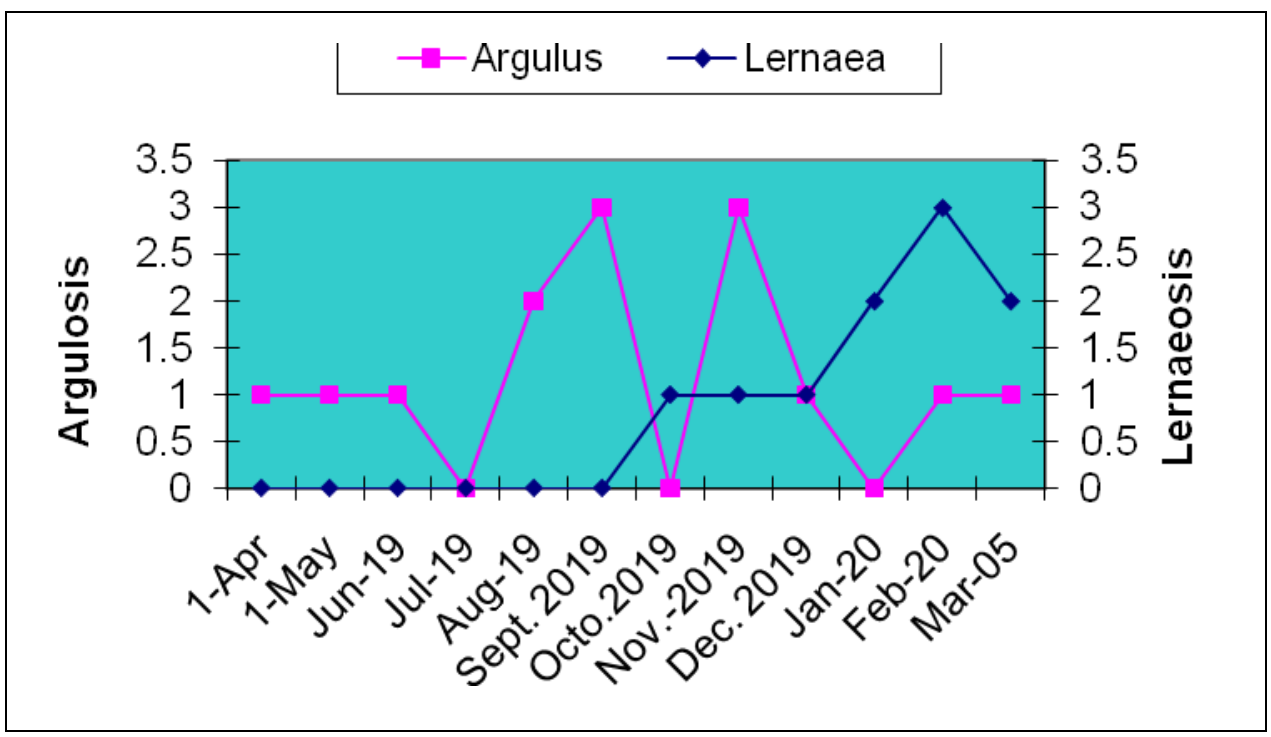

Fig.7 Incidence of crustacean parasitic diseases

In parasitic diseases, the helminth disease occurrence is higher than that of protozoan and crustacean diseases. In helminth diseases, the dactyologyrosis cases are more (491 43.3\%) than Paradactylogyrosis cases (484 42.7\%) (Table 3, Fig. 1, 2a, 2b). In protozoan, the cases of Myxosporiasis $(111-9.8 \%)$ are higher than that of Trichodiniasis $(22-2.1 \%)$ (Table 3, Fig. 1, 4a, 4b) and in Crustacean diseases the occurrence of Argulus cases $24-$ $2.1 \%$ are higher than that of Lernaea (10) (Table 3, Fig. 1, 6a, 6b).

In parasitic diseases, dactylogyrosis is infected by dactylogyrus, paradactylogyrosis is by paradactylogyrus. The myxosporiasis is caused by myxobolus and trichodiniasis by trichodina. In crustacean diseases, argulosis is caused by Argulus sps and lernaeosis is caused by lernae (Table 2). Though the occurrence of parasitic diseases is throughout the year but their occurrence is more at rainy and winter season (Fig. 3, 5 and 7).

The production from culture system is hampered by infestation of various fish parasites. Compared to other diseases, occurrence of parasitic diseases has been the major cause of concern and caused significant setback to freshwater aquaculture in India (Sahoo, 2013). Fish parasites multiply rapidly under favourable conditions, there by affecting the health of fishes, often leading to high mortality. Parasites interfere with 
nutrition of hosts, disrupt metabolism and secretary functions of alimentary canal and damage the nervous system (Das and Mishra, 2014, Farhaduzzaman et al., 2010). During survey of different carp farms (Table 1) in Andhra Pradesh, fish were observed to be affected by fish parasites (Table 2), mostly, protozoan ciliates (Ichthyophthirius sps, Trichodina sps), monogenetic trematodes (Dactylogurus sps, Gyrodactylus sps) and larger crustacean ectoparasites viz Lernaea spp, Argulus sps (freshwater louse), Ergasilus, which cause substantial economic loss in fish culture system in India (Sahoo et al., 2013). Disease and mortality due to Monogenian trematodes, Gyrodactylus sps (commonly known as skin flukes) and Dactylogyrus sps (known as gill flukes) have also been commonly reported in carp culture. These monogenetic trematodes are considered as one of the most prevalent parasitic agents affecting skin and gills, causing irritation and destruction of gill tissues leading to impairment of breathing. The Ichthyopthirius cause "white spot" or Ich in the freshwater fishes. Another parasite Trichodina browse over gills and skin damaging the host tissue and consuming the resulting dead tissues (Fig. 6b). Another important and most prevalent parasitic disease causing severe economic loss in carp culture is "Argulosis" caused by crustacean ectoparasites of the genus Argulus also called "Freshwater fish lice". Acute infestation of Argulus infestations often cause dermal ulceration, osmotic imbalance, physiological stress and immunosuppression, leading to high morbidity and lowered growth rate of carps (Mukharjee, 2002; Farhaduzzaan, 2010), but the incidence of mass mortality due to this disease has been very low (Monir et al., 2015). It is reported that Indian major carps are more susceptible to Argulus parasites (Table 2, 3). The intensity of infestation is greatly influenced by seasonality (Fig. 6a, 7), which affects host physiology and ecology (Mukharjee, 2002;
Momir et al., 2015). Intense parasite infestation can cause ulceration and upset the normal course of reproduction (Farhaduzza Man et al., 2010). Besides, indirect effects of infestation seen as reduced fish growth, reduced feed conversion ratio, secondary infections with other bacterial and parasitic infestations and fish mortality as well as farmers perception about safe aquaculture, too contribute substantially to the loss incurred (Mukharjee, 2002).

Another significant observation in IMC culture is the seasonal variation in occurrence and severity of fish diseases in carp culture (Fig. 3, 5, 7). Among parasitic diseases, occurrence of Argulosis and gill flukes diseases are comparatively more during winter and post rainy seasons (Fig. 3, 7). The mortality rate is also higher in winter season (Table 4). The water quality of some culture ponds are maintained in optimum level (Table 5 ). Hence the farmers are advised to take due preventive and control measures during post rain and winter seasons, in grow out culture systems.

In conclusion, the transformation of Aquaculture activity from traditional to commercial scale, has led to drastic increase of production levels, simultaneously earning crores of rupees through export. Due to lucarativeness, the farmers are proceeding from semi intensive to intensive culture practices along with heavy inputs. The heavy inputs of feed, fertilizers, chemicals and probiotics bring in lot of changes in water quality parameters, resulting in negative effects, which lead to stress and finally occurrence of diseases.

In the survey 1132 cases of parasitic diseases are observed. In parasitic diseases, $43.3 \%$ of dactylogyrosis $\quad 43.3 \%$ and $42.7 \%$ paradactylogyrosis are being reported in carp culture ponds. In parasitic diseases 
dactylogyrosis, paradactylogyrosis and argulosis are observed to be very frequent in occurrence and bring out heavy economic loss, which also coincides the reports of (Mukharjee, 2002; Mohanty and Sahoo, 2007). Irrespective of the season the parasitic diseases are noticed throughout the year wherein poor management of water quality parameters, feed and health management is in practice. The development of suitable preventive and control measures, specific therapy for fish diseases assumes paramount significance, for the farmers to protect their crop against pathogens. The implementation of Better Management Practices (BMP) is most important, to prevent frequent occurrence of disease and production loss in aquaculture. Further enhancement in knowledge about the disease process, host pathogen and the environment interaction leading to disease occurrence, are very much essential, (Subasingha, 2001). This needs immediate due attention by the farmers for attaining of higher yields. Farmers are now in practice of using various probiotic formulations, aqua drugs and chemicals, various antimicrobials, sanitizers, antiparasitic drugs and even antibiotics in fish culture system, as preventive and control measures to protect the crops (Anon, 2017; Mishra et al., 2017; Anon et al., 2017). But in view of all these a good understanding of disease prevalence status, indigenous technologies for disease prevention and control, implementation of farm level best management practices and husbandry measures are the key components which must be given due attention for sustainable fisheries production in the region.

\section{Acknowledgement:}

The author is highly thankful to the Director of Research, Sri Venkateshwara Veterinary University for providing the necessary facilities for carrying out this work.

\section{References}

Anon: Cifax Fish Medicine, Agrawal Trading Company, Raipur, Chhattisgarh, India (https//:www.indiamart.com/proddetail/ci fax-fish-medicine - 12936885597.html) (2017).

Anon: Aquaculture Production in India. J. Aqua. Fisheries (2017).

Bagum N, monir M.S., Khan M.H.: Present status of fish diseases and economic due to incidence of disease in rural freshwater aquaculture of Bangladesh. J. Innov Dev. Strategy 7: 48-53 (2013).

Bondad - Reanrago M.G., Subasinghe R.P., Arthur, J.R., Ogawa, K., Chinabut S, et $a l$., Disease and health management in Asian aquaculture. Vet Parasitol. 132:249-272 (2005).

DADF: Guidelines: Central sector scheme on blue revolution: Integrated development and management of fisheries. Department of Animal Husbandry, dairying and fisheries, Ministry of agriculture and farmers welfare, government of India, India (http://dahd.nic.in.sites/default/files/guide lines/ BR - 30616. Fisheries. Pdf (2016).

Das B.K., Misha S.S.: Diseases in Freshwater Aquaculture, In: Training Manual on model training course on preventive health management practices in freshwater aquaculture. ICAR - Central Institute of Freshwater Aquaculture, Bhubaneswar, Odisha, India (2014).

Farhaduzzaman A.M, Alam, M.M, Hossain M, Hussain M.A, Rahman M.H.: Prevalence of parasitic in the Indian Major Carp, Labeo rohita (Hamilton) in Rajshahi, Bangladesh 28: 65-68 (2010).

Jelte, de Jong: Aquaculture in India, Rijksdienst Voor Ondernemend Nederland. (https://www.rvo.nl.sites/default/files/201 7/04/aquauclture-in-india-report2017.pdf) (2017).

Mishra S.S., Dhiman M., Swari, P, Das, B.K.: Fish disease and health management issues in aquaculture ICAR - CIFA 
Training manual No. 18, Central Institute of Freshwater Aquaculture, Bhubaneswar, India (2015).

Mishra, S.S., Das, R., Das, B.K., Choudhary, P., Rathora, R. et al., Status of Aqua medicines, Drugs and Chemicals use in India. A survey report J. Aqua. Fisheries (2017).

Mohan C.V., Bhatta R.: Social and economic impacts of aquatic animal health problems on aquaculture in India In: Arthur J.R., Philips M.J, Subasinghe R.P., Reantago M.B., Mac Rae (eds), Primary aquatic animal health care in rural, small scale, aquaculture development. Food and Agriculture Organization of the United Nations, Rome, Italy (2002).

Mohanty, B.R., Sahoo, P.K.: Edwardsiellosis in fish a brief review. J. Biosci 32: 1331 1344 (2007).

Monir, Md. Shirajum, Bagum, N, Rahman, S. Ashaf - Ud - Doulah Mohammad, Bhadra A, et al., Parasitic disease and estimation of loss due to infestation of parasites in Indian major carp culture ponds in Bangladesh. International Journal of Fisheries and Aquatic studies 2: 118 -122 (2015).

Mukharjee, S.C.: Fish diseases in India, their causes and control measures - Winter school on recent advances in diagnosis and management of disease in maricutlure, $7^{\text {th }}$ to $27^{\text {th }}$ November 2002, course Manual, Central Marine Fisheries Research Institute, Cochin, India (2002).

Sahoo P.K., Mohanty, J., Garnayak, J.S.K., Mohnaty B.R., Kar Banya: Estimation of loss due to argulosis in carp culture ponds in India. Indian J. Fish. 60: 99-102 (2013).

Sahoo, P.K., Pradhan, P.K., Sundaray, J.K., Lal, K.K., Swaminathan, T.R.: Present status of freshwater fish and shellfish diseases in India. In: Proceedings of International symposium on Aquatic Animal Health and Epidemiology for sustainable Asian Aquaculture. ICAR National Bureau of fish genetic resources (2017).

Shaoqui, Li.: Main fish diseases and their control. In integrated Fish Farming in China (ed). NACA Technical Manual 7. A World Food Day Publication of the Network of Aquaculture Centres in Asia and the Pacific, Bangkok, Thailand (1989).

Snieszko, S.F.: The effects of environmental stress on the outbreaks of infectious disease of fish. Journal of Fish Biology 6: 197-208 (http://onlinelibrary.wiley.com/doi/10.111 1/j.1095-8649. 1974.tb04537.X/abstract) (1974).

Subasinghe, R.P., Bondad - Reantago, M.G., Mc Gladdary S.E.: Aquaculture development, health and wealth In: Subasinghe R.P., Reantago MQB, Mc Gladdary S.E. (Eds). Aquaculture in the Third Millennium Technical proceedings of the conference on Aquaculture in the Third Millennium, Bangkok, Thailand Pg. No: 167-191 (2001).

Vijayan, K.K., Sanil, N.K.: Health Management Strategies for profitable and sustainable aquaculture, with special reference to diagnostics. In: Swain, S.K., Swain, P., Pillai, B.R., Raghunath, M.R., Jayasankar, P. (eds). Lead papers on strategies for Aquaculture Development ICAR - Central Institute of Freshwater Aquaculture, Bhubaneswar, India (2012).

Walker, P.J., Winton, J.R.: Emerging viral disease of fish and shrimp. Vet Res. 41:51 (https://www.nebi.nlm.nih.gov/pmc/articl es/PMC2878170) (2010).

\section{How to cite this article:}

Suguna, T. 2020. Survey on Occurrence of Parasitic Diseases in Carp Culture Ponds of West Godavari, Andhra Pradesh Int.J.Curr.Microbiol.App.Sci. 9(10): 2306-2315. doi: https://doi.org/10.20546/ijcmas.2020.910.278 